Original Research Paper

\title{
Study of Au/n-Ti 2 S/p-Si/Al Schottky-Type Thin Film Heterojunction Solar Cells: Computer Simulation Modeling
}

\author{
Ali Ibrahim \\ Department of Physics, Faculty of Science, Tanta University, 31527 Tanta, Egypt
}

\author{
Article history \\ Received: 17-10-2014 \\ Revised: 19-11-2014 \\ Accepted: 30-04-2015 \\ E-mail: ali_02us@yahoo.com
}

\begin{abstract}
The $\mathrm{Au} / \mathrm{n}-\mathrm{Ti}_{2} \mathrm{~S} / \mathrm{p}-\mathrm{Si} / \mathrm{Al}$ heterojunction with intrinsic thin-layer solar cells were analyzed by AFORS-HET software program. Thickness of the emitter intrinsic layer and the interface state density of such cells were studied. In which, the intrinsic layer inserted between the $\mathrm{Ti}_{2} \mathrm{~S}$ and crystalline p-type silicon substrate, reduce the interface state density. The thinner intrinsic layer is better than thicker one, when the interface state density is lower than $10^{10} \mathrm{~cm}^{-2} \cdot \mathrm{V}^{-1}$. As the thickness of the emitter increased, both short-current density $(\mathrm{J})$ and the conversion efficiency were decreased. The dependence of $\mathrm{J}-\mathrm{V}$ characteristics of the $\mathrm{Au} / \mathrm{n}-\mathrm{Ti}_{2} \mathrm{~S} / \mathrm{p}-\mathrm{Si} / \mathrm{Al}$ heterojunction solar cell on Front and back Surface Recombination Velocity (SRV) was studied. By optimizing the initial parameters set, the $\mathrm{Au} / \mathrm{n}-\mathrm{Ti}_{2} \mathrm{~S} / \mathrm{p}-\mathrm{Si} / \mathrm{Al}$ solar cell reaches a high efficiency $(\eta)$ up to $21.849 \%$ (FF: $0.834, \mathrm{~V}_{\mathrm{oc}}: 0.666 \mathrm{~V}, \mathrm{~J}_{\mathrm{sc}}: 39.39 \mathrm{~mA} / \mathrm{cm}^{2}$ ).
\end{abstract}

Keywords: AFORS-HET Software, Computer Simulation, Heterojunction Solar Cells, Intrinsic Emitter Layer Thickness, Interfaces States Density

\section{Introduction}

A silicon solar cell is a typical photovoltaic cell fabricated from poly-silicon and monocrystalline silicon solar cells with conversion efficiency of 19.8 and $24.4 \%$, respectively (Zhoa et al., 1998). The amorphous silicon solar cell of multilayered $\mathrm{p}-\mathrm{i}-\mathrm{n}$ unit cell structure with a high open voltage of $2.0 \mathrm{~V}$ has been developed by (Hamakawa et al., 1979). A conversion efficiency of $17.0 \%$ of the thinner solar cells fabricated by (Reuter et al., 2009) has been obtained. To improve the conversion efficiency, the front surface of a solar cell was generally textured (Muller et al., 2004). To facilitate efficient light trapping, an additional textured photonic crystal and backside reflector were fabricated on the back surface (Zeng et al., 2008).

The simulated device performance is strongly related to the doping of the $n-\mathrm{Ti}_{2} \mathrm{~S}$ layers. Sufficient doping and layer thickness has to be chosen to introduce the band bending at the $\mathrm{n}-\mathrm{Ti}_{2} \mathrm{~S} / \mathrm{p}$-Si interface determining the built-in voltage and therefore the upper limit of $\mathrm{V}_{\mathrm{oc}}$ (Stangl et al., 2004; Leendertz et al., 2011; Schulze et al., 2011; Chen and Zhu, 2012). However, with high doping the junction recombination can increase $\mathrm{V}_{\mathrm{oc}}$ is lowered for doping concentration above a certain level (Chakraborty et al., 2013; Haque et al., 2013). A fundamental problem when contacting the ptype $\mathrm{Si}$ with the n-type $\mathrm{n}-\mathrm{Ti}_{2} \mathrm{~S}$ transparent conductive oxides TCO's is the formation of a Schottky barrier. To account for the Schottky barrier, a higher $\mathrm{n}-\mathrm{Ti}_{2} \mathrm{~S}$ doping and/or layer thickness are required, which can lead to a trade-off between $\mathrm{V}_{\mathrm{oc}}$ and $\mathrm{FF}$ and $\mathrm{J}_{\mathrm{sc}}$ and $\mathrm{FF}$, respectively (Martın de Nicolas et al., 2011; Saron et al., 2013). A solar cell design characterized by a silicon heterojunctions SHJ (emitter) only at the rear and a diffused Front Surface Field (FSF) featuring negligible parasitic absorption at the front to overcome these limitations (Bivour et al., 2010; 2011; Wunsch et al., 2006). The design of such solar cell is referred as a hybrid SHJ solar cell. This device structure is featuring a well-known and robust front and allows an increased degree of freedom for the design of the SHJ since parasitic absorption in the $\mathrm{n}-\mathrm{Ti}_{2} \mathrm{~S}$ layers tack is not an issue. Therefore, junction optimization can be focused on carrier transport and/or carrier recombination. A contact layer for a wide range of higher TCO can be used, indispensable for its lateral conductivity at the front of SHJ solar cells, is not mandatory for the rear SHJ.

In this study, The characteristics of $\mathrm{Au} / \mathrm{n}-\mathrm{Ti}_{2} \mathrm{~S} / \mathrm{p}$ $\mathrm{Si} / \mathrm{Al}$ hetrojunction (HIT) solar cells based on silicon a solar cell structure designed with AFORS-HET simulation program have been studied. Also, the best TCO layer regarding the work function, in addition to the required low interface state density at the silicon surface has been determined. 


\section{Solar Cell Simulation Tools}

The simulation programs are mostly reduced to one dimensional analysis as compared with highly expensive commercial programs, which can make two and three dimensional device simulations and requiring workstations for running. The simulation programs solve numerically the Poisson equations (charge neutrality), in addition the continuity equations for holes and electrons. The boundary conditions and some effects associated with the interfaces in a solar cell (such as, interface carrier recombination) is the fundamental difference in the way that they handle.

SimWindow is a freely available one dimensional drift/diffusion simulator for semiconductor devices. ADEPT-F from the group of Jeff Gray, Purdue University (Gray et al., 1991) has been widely used. The program ASPIN of the University of Ljubljana (Smole et al., 1994) has been used for CIGS cells and for a: Si cells. AFORSHET has been developed by a group of the HahnMeitner Institute of Berlin (Froitzheim et al., 2003) for simulating hetero-junction solar cells. Programs such as SILVACO-ATLAS (Michael and Michalopoulos, 2002) and Cross Light-APSYS (Brown et al., 2010) are expensive programs used in the silicon microelectronic industry; they are also usable for solar cells, especially for developing microelectronic devices and also implement a multi-dimensional (two-or three-dimensional) simulation of Si wafer processing. In the case of polycrystalline thinfilm solar cells require of two-or even three-dimensional programs because of grain boundaries and non-planar interfaces. Grain boundary effects seem to be more prominent in CdTe cells than in CIGS cells. Though onedimensional problems effectively average the effect of grain boundary states over the bulk, they have been surprisingly successful.

\section{Solar Cell Numerical Modeling}

Before any simulation process for a solar cell, a good understanding of the cell structure and the physical parameters involved is required. This sometimes is not possible because there is not a full characterization of the real cell structure. As example. The real structure for $\mathrm{CdS} / \mathrm{CIGS}$ solar cells is not well known because an interfacial layer between the CdS and the CIGS layer may appear with special properties depending upon the cell preparation method. It has been suggested that close to this interface a thin inversion (n-type) CIGS layer exist in contact with a more stoichiometries p-type CIGS layer. Some parameters which are well known for bulk materials are not adequately known for thin polycrystalline materials and therefore it is not easy to select the appropriate values for simulating the solar cells based on such materials. The existence and properties of such layer depends upon the deposition method and conditions for both the CIGS and the CdS layers. Moreover, the efficiency of solar cells has been obtained experimentally, but not the properties of each of the layers and vice versa.

\section{Results and Discussion}

The light $\mathrm{J}-\mathrm{V}$ characteristics, at the spectrum of air mass 1.5 used in the AFORS-HET software modeling tool is shown in Fig. 1b. This corresponds to a power density of $100 \mathrm{~m} \mathrm{~W} / \mathrm{cm}^{2}$. The values of cell parameters including short circuit current density $\left(\mathrm{J}_{\mathrm{sc}}=36 \mathrm{~mA} / \mathrm{cm}^{2}\right)$, open circuit voltage $\left(\mathrm{V}_{\mathrm{oc}}=0.650 \mathrm{~V}\right)$, fill factor $(\mathrm{FF}=$ $82 \%$ ) and efficiency of the cell is $18.5 \%$. At the same time, the schematic diagram of the fabricated $\mathrm{Au} / \mathrm{n}$ $\mathrm{Ti}_{2} \mathrm{~S} / \mathrm{psi} / \mathrm{Al}$ HIT thin film solar cell is shown in Fig. 1a.

The dark current-voltage curve of $\mathrm{Au} / \mathrm{n}-\mathrm{Ti}_{2} \mathrm{~S} / \mathrm{p}-\mathrm{Si} / \mathrm{Al}$ heterojunction in both forward and reverse bias is shown in Fig. 2. The formation of a depletion region between $\mathrm{Ti}_{2} \mathrm{~S}$ layer and $\mathrm{Si}(111)$ single crystal is probably the reason for exponential dependence of the forward current in the lower voltage range. It is evident that the junction exhibits strong rectifying characteristics showing diodelike behavior. According to the relation:

$\mathrm{R}_{r}=\left(\mathrm{I}_{\mathrm{f}} / \mathrm{I}_{\mathrm{r}}\right) \mathrm{V}=\mathrm{const}$

The rectification ratio, $R_{r}$, (the ratio of the forward current to the reverse current at a certain applied voltage), of the $\mathrm{Au} / \mathrm{n}-\mathrm{Ti}_{2} \mathrm{~S} / \mathrm{p}-\mathrm{Si} / \mathrm{Al}$ heterojunction thin film solar cell can be obtained.

\section{Optimization of the Intrinsic Layer Thickness}

Photovoltaic characteristics of High Efficiency Computer Simulation HECS solar cell vary with the thickness of the intrinsic layer I is shown in Fig. 3. From the data it is evident that, the conversion efficiency of HECS is up to $19.27 \%$ with $1 \mathrm{~nm}$ intrinsic layer is inserted, which is $0.4 \%$ higher compared with no intrinsic layer solar cell. But as I layer thickness increases, the conversion efficiency decreases. When the thickness of an intrinsic layer reaches $5 \mathrm{~nm}$, the conversion efficiency of HECS solar cell with intrinsic layer is equivalent to solar cell with no intrinsic layer. Compromising the production processes and the conversion efficiency, the optimal intrinsic layer thickness should be set at $3 \mathrm{~nm}$. In addition, from Fig. 3, we can see that, with the increase of intrinsic layer thickness, the open circuit voltage keeps almost unchanged, while the short circuit density decreases. This is because, as I layer thickness increases, the electric field strength of space charge region decreases and the short-spectrum absorption of amorphous silicon increases. The corresponding light-induced carriers cannot be effectively collected, resulting in the decrease of short circuit current density. 


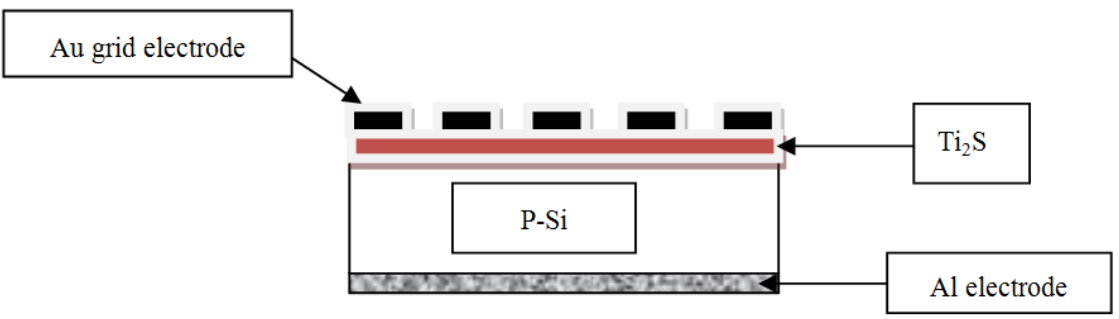

(a)

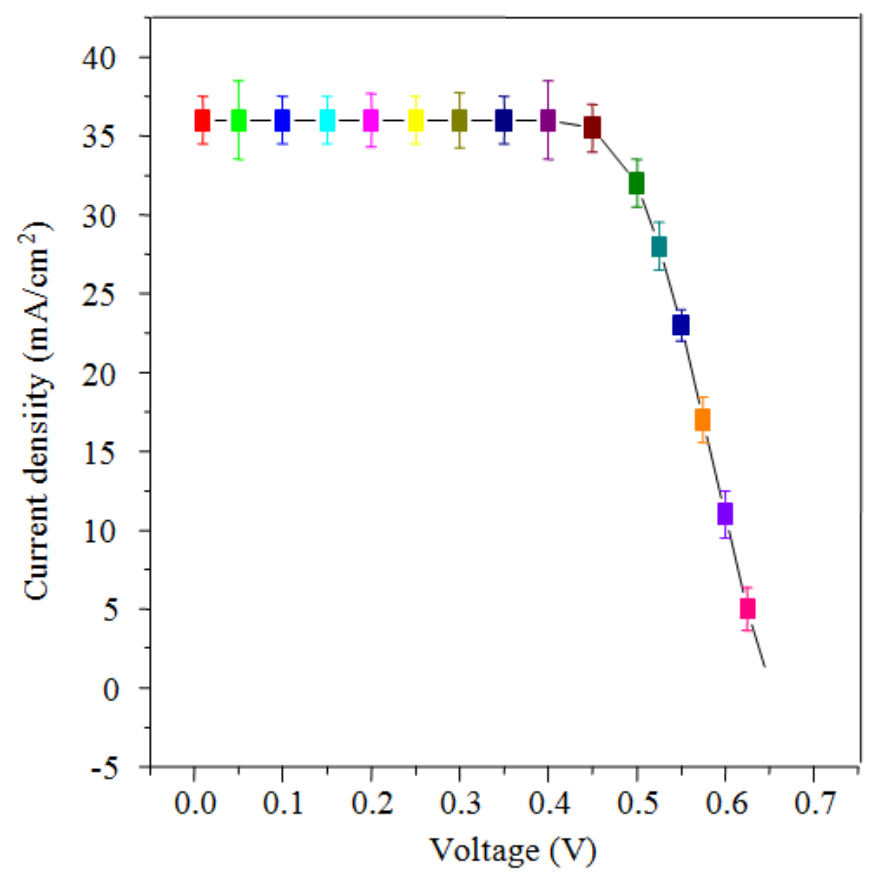

(b)

Fig. 1. (a) Schematic diagram of the $\mathrm{Au} / \mathrm{n}-\mathrm{Ti}{ }_{2} \mathrm{~S} / \mathrm{p}-\mathrm{Si} / \mathrm{Al}$ thin film solar cell at room temperature and (b) The J-V curve of the Au/n$\mathrm{Ti}_{2} \mathrm{~S} / \mathrm{p}-\mathrm{Si} / \mathrm{Al}$ thin film solar cell

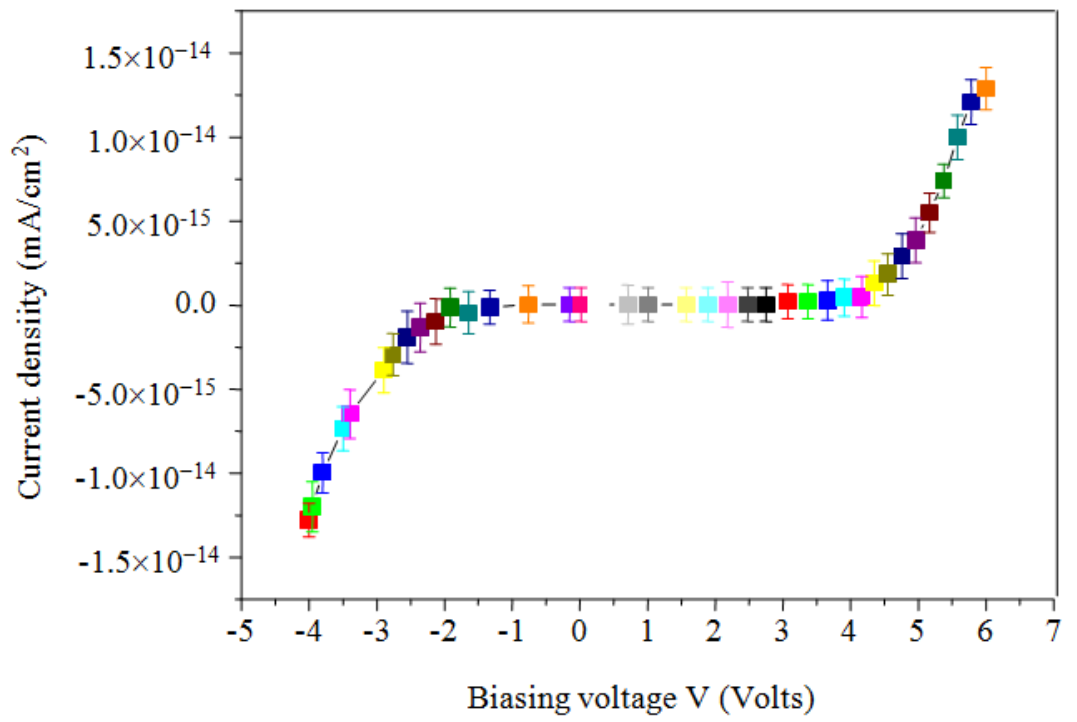

Fig. 2. The current density varies biasing voltage of $\mathrm{Au} / \mathrm{n}-\mathrm{Ti} \mathrm{i}_{2} \mathrm{~S} / \mathrm{p}-\mathrm{Si} / \mathrm{Al}$ cell 


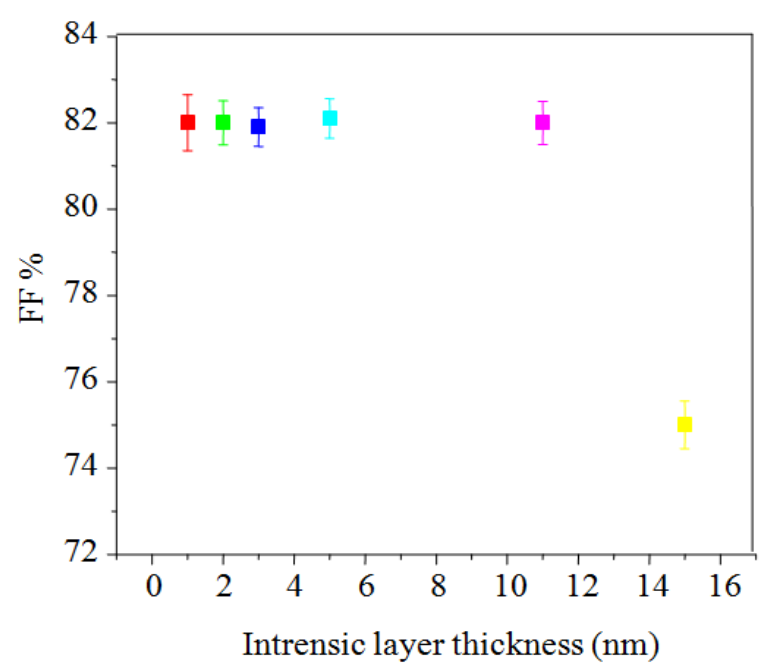

(a)

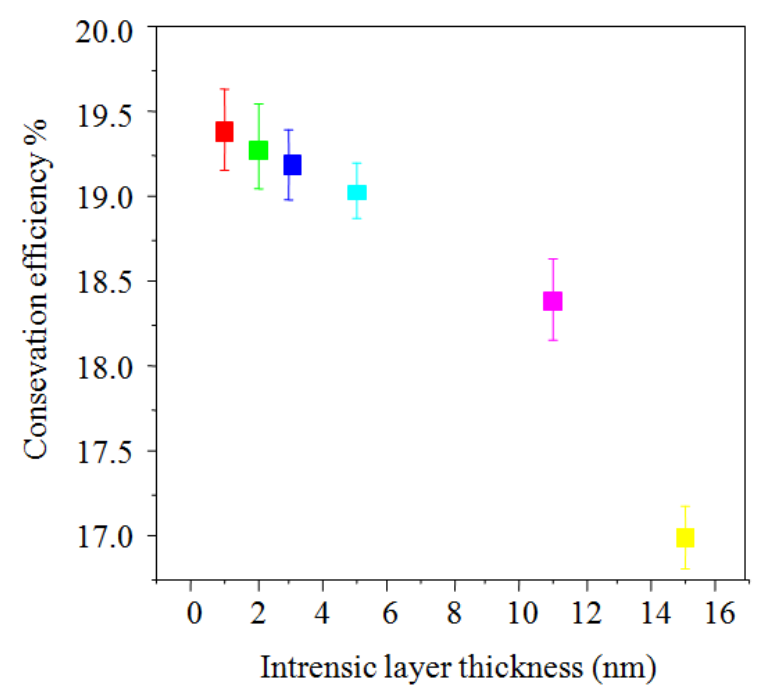

(c)

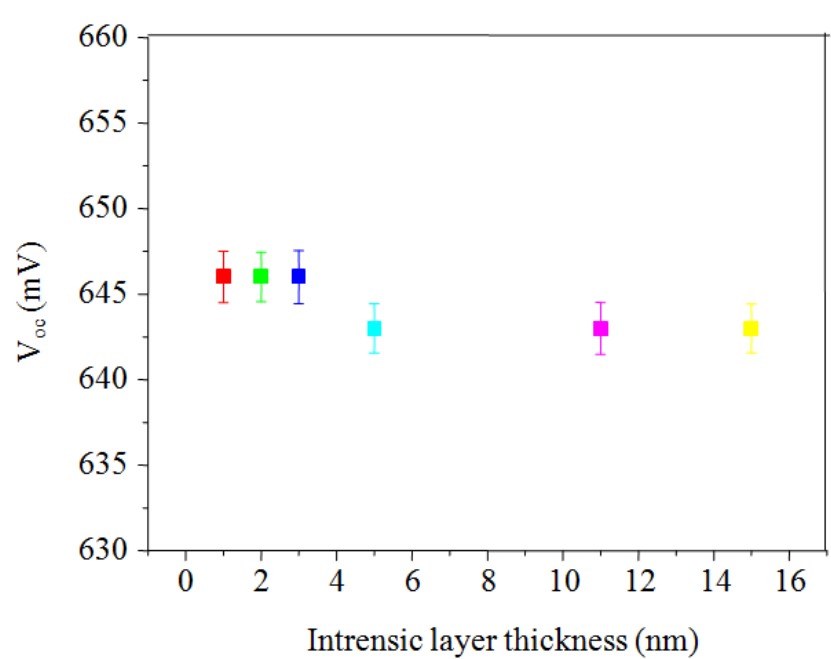

(b)

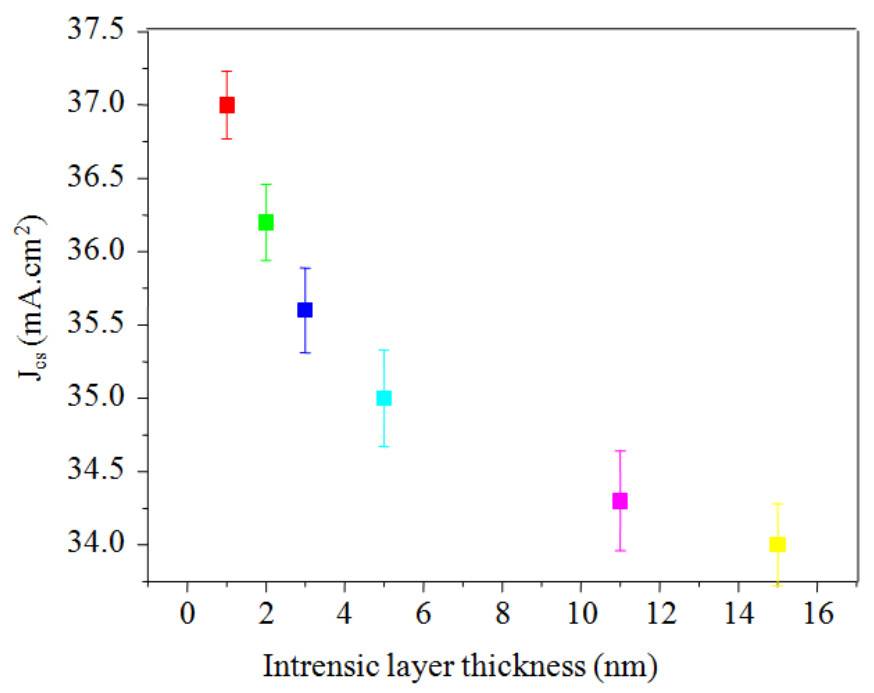

(d)

Fig. 3. The performances of $\mathrm{Au} / \mathrm{n}-\mathrm{TiI}_{2} \mathrm{~S} / \mathrm{p}-\mathrm{Si} / \mathrm{Al}$ solar cell vary with the intrinsic layer thickness: (a) $\mathrm{V}_{\mathrm{oc}}$, (b) $\mathrm{FF}$, (c) $\mathrm{J}_{\mathrm{sc}}$ and (d) conversion efficiency $\%$

\section{The Influence of the Interface State Density on the HECS Performances}

For the actual solar cell production processes, the impact of interface state density cannot be ignored. In this study, the interface defect states are assumed to insert between the layer and the p-type crystalline silicon substrate layer. The interface states are assumed as continuous donor-like states and acceptorlike states with an average distribution in the band gap, with the capture cross sections of electron and hole both are $10^{-14} \mathrm{~cm}^{2}$. Theinterface state density of $\mathrm{n}-\mathrm{Ti}_{2} \mathrm{~S} / \mathrm{p}-\mathrm{Si}$ interface varies from $10^{9} \mathrm{~cm}^{-2} \cdot \mathrm{eV}^{-1}$ to $10^{13} \mathrm{~cm}^{-2} \cdot \mathrm{eV}^{-1}$ and its effects on the photovoltaic performances of the solar cell are shown in Fig. 4.
As the emitter thickness increases, the open circuit voltage changed little, while the short circuit current is dramatically reduced as shown in Fig. 5. This is because as the emitter thickness increases, the absorption of the photon in emitter has increased. Considering the large amounts of recombination centers and the feature of no electric field in emitter, the photo-induced carriers are impossible to reach the edge of space charge region and contribute to light current. On the contrary, they will be recombined in the region and disappeared, resulting in the reduced short-spectrum response and short-circuit current. Fill factor also decreases with the $\mathrm{n}$ region thickness increases. While, as the $\mathrm{n}$ layer thickness increases, series resistance will increases, which will reduce the fill factor (Ren et al., 2008). 


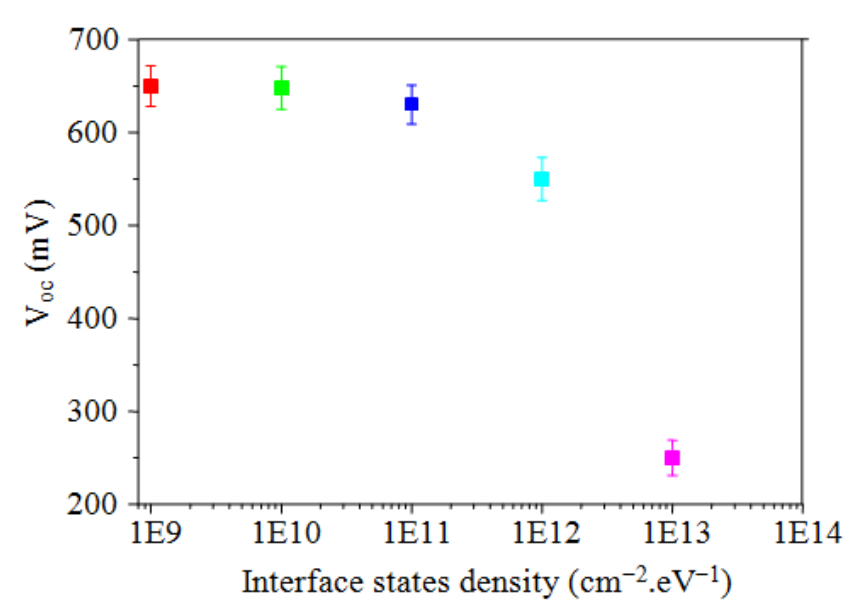

(a)

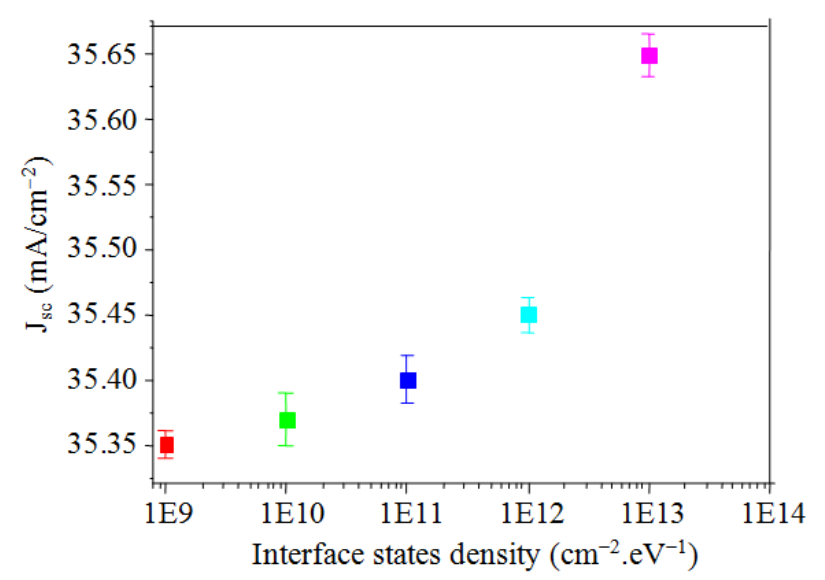

(c)

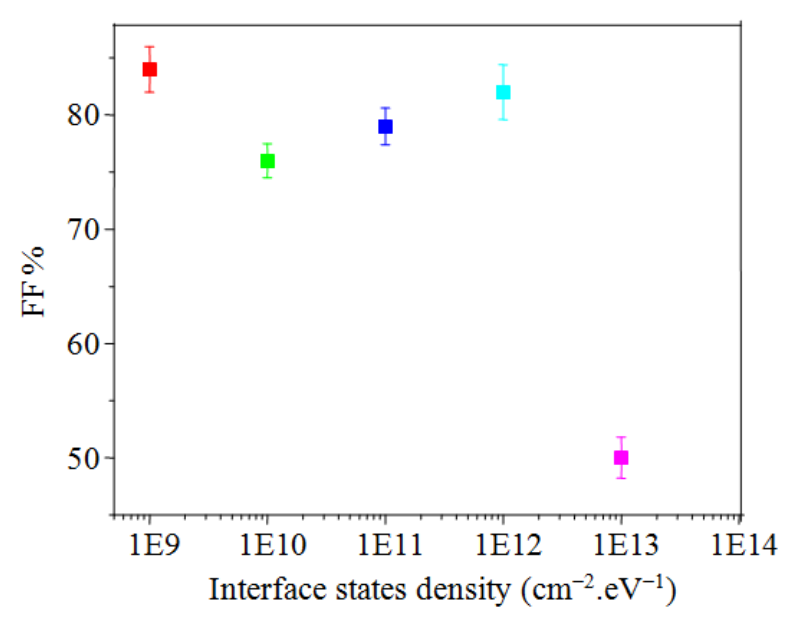

(b)

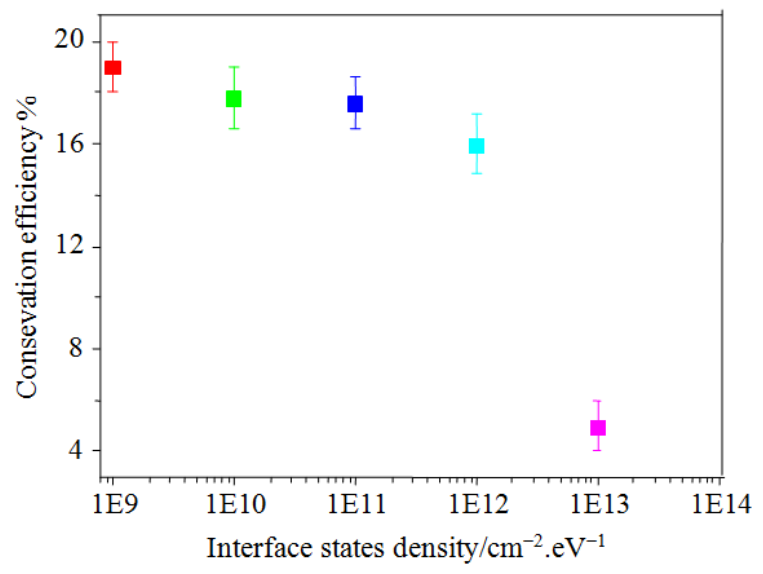

(d)

Fig. 4. The impact of interface states density on the photovoltaic performances of HECS solar cell: (a) $V_{o c}$, (b) FF, (c) $J_{s c}$ and (d) conversion efficiency $\%$

\section{Simulation of Dark I-V Characteristics of the Au/n-} $\mathrm{Ti}_{2} \mathrm{~S} / \mathrm{p}$-Si/Al Heterojunction Solar Cell

The conduction mechanisms' information can be obtained by plotting current-voltage curves at different temperatures. Semi logarithmic plots of the forward current-voltage for an $\mathrm{Au} / \mathrm{n}-\mathrm{Ti}_{2} \mathrm{~S} / \mathrm{p}-\mathrm{Si} / \mathrm{Al}$ heterojunction in the dark are given in Fig. 6. It is clear from the figure that, there are two different conduction mechanisms which characterize these curves for the two distinct regions. The exponential behavior, within the narrow, low forward voltage $(V \leq 0.5 \mathrm{~V})$, agrees with rectification characteristics which are generally described by different models (Oueriagli et al., 1992). These data in the range $(V \leq 0.5 \mathrm{~V})$ were fitted using the Schottky Equation 2 (Sze, 1981):

$$
I=I_{s}\left[\exp \left(\frac{e V}{n k_{B} T}\right)-1\right]
$$

where, $\mathrm{k}_{\mathrm{B}}$ is Boltzmann's constant, $n$ is the diode quality factor and $I_{S}$ is the saturation current which can be obtained by extrapolating the $\ln \mathrm{I}-\mathrm{V}$ portion to the $\ln \mathrm{I}$ axis at zero voltage and found to be $8.3 \times 10^{-7} \mathrm{~A}$ at room temperature and increases with increasing elevated temperatures to be of $3.3 \times 10^{-6} \mathrm{~A}$ at $363 \mathrm{~K}$ as shown in Fig. 6. The diode quality factor $n$ is found to be independent of temperature in the investigated range. This behavior indicates thermionic emission mechanism in the cell under investigation. The recombination of electrons and holes in the depletion region and/or the increase of the diffusion current due to increasing the applied voltage leads to the change of the diode quality factor from unity (Rhoderick, 1978; Van and Potje-Kamloth, 2001; El-Nahass et al., 2005; Forrest et al., 1984).

The temperature dependence of electrical resistivity for $\mathrm{Ti}_{2} \mathrm{~S}$ thin films of different thicknesses is shown in Fig. 7. 


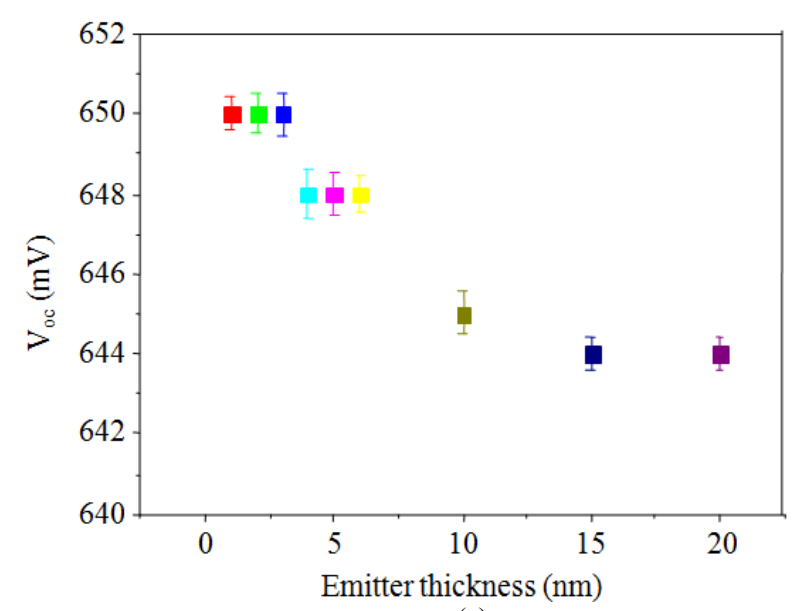

(a)

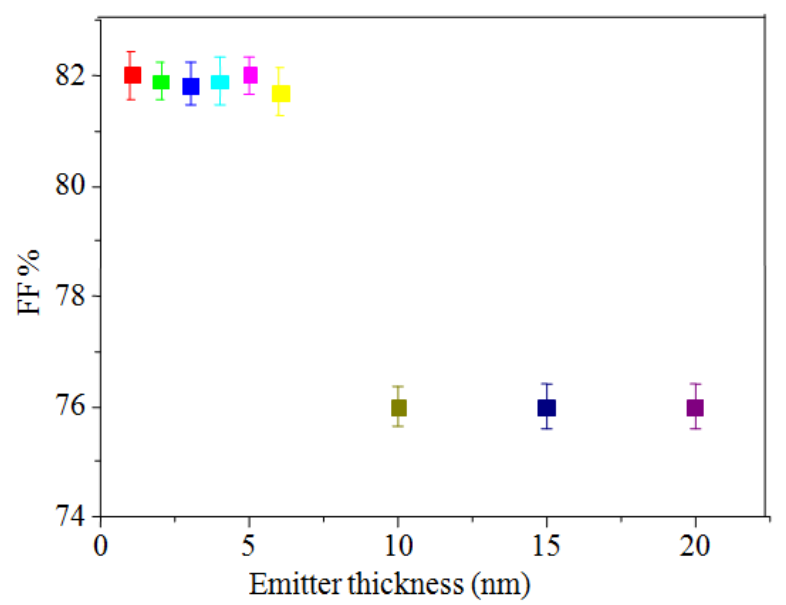

(c)

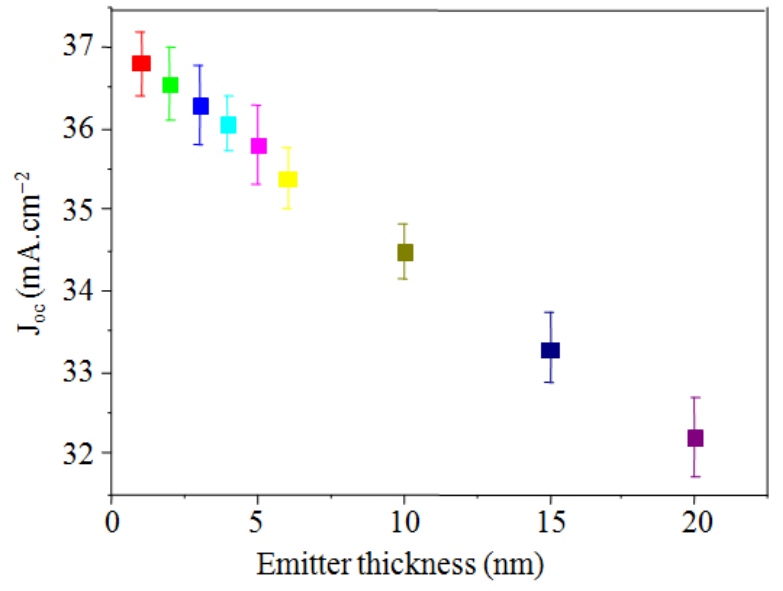

(b)

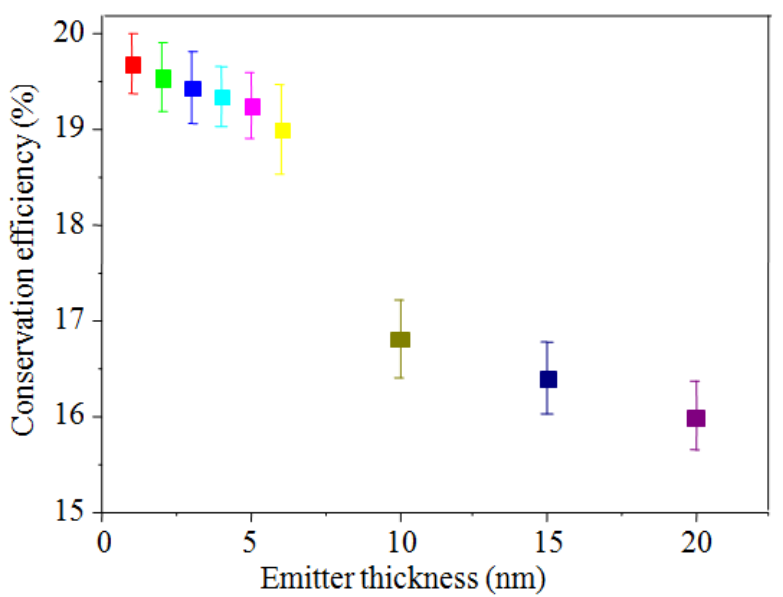

(d)

Fig. 5. The impact of emitter thickness on the photovoltaic properties of HIT solar cell: (a) $V_{o c}$, (b) FF, (c) $J_{s c}$ and (d) conversion efficiency $\%$

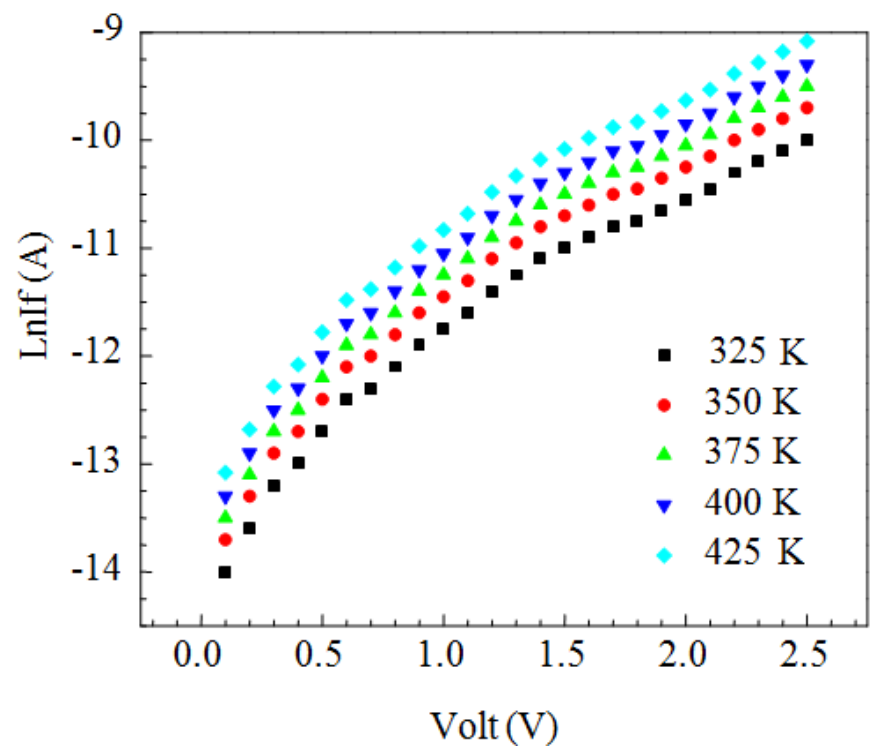

Fig. 6. Semi logarithmic plots of the forward bias of $\mathrm{I}-\mathrm{V}$ characteristics at different temperatures for $\mathrm{n}-\mathrm{Ti}_{2} \mathrm{~S} / \mathrm{p}-\mathrm{Si}$ heterojunction 


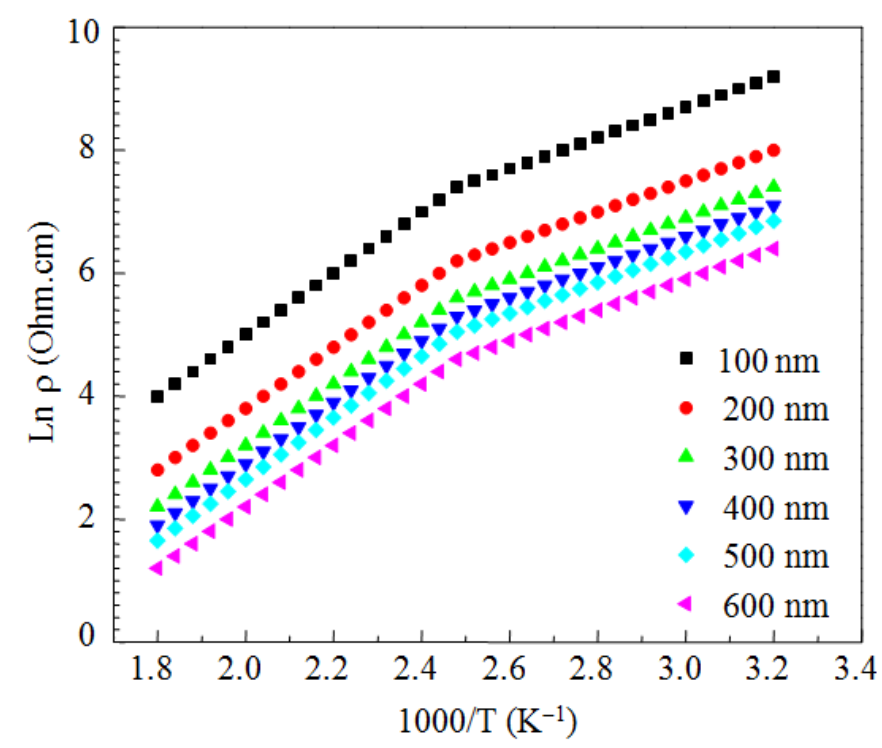

Fig. 7. Relation between Ln resistivity ( $\rho$ ) and $1000 / \mathrm{T}$ for $\mathrm{Ti}_{2} \mathrm{~S}$ films of different thicknesses

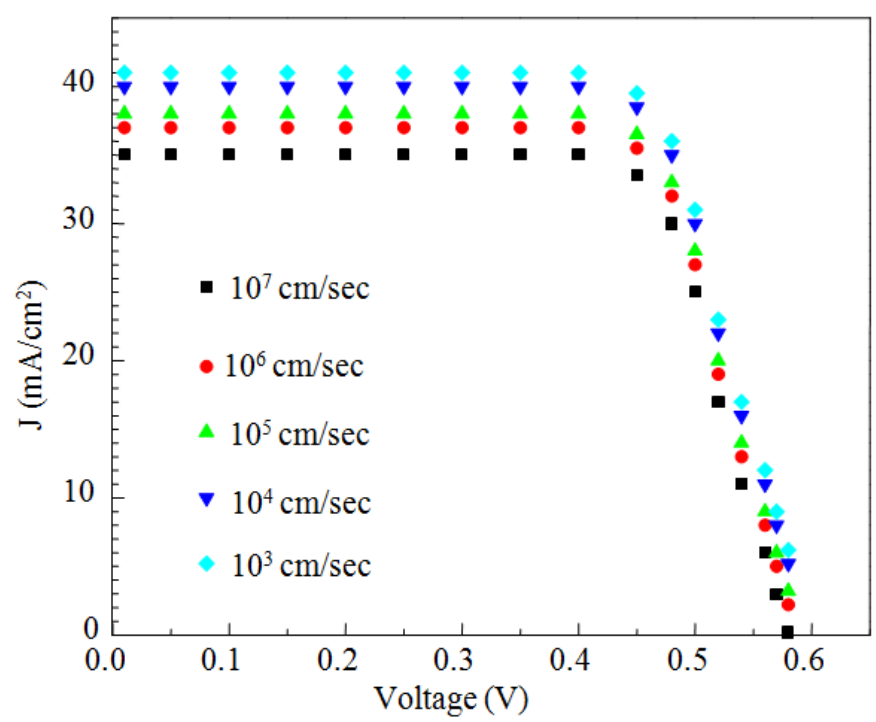

Fig. 8. Simulated J-V characteristics various values of S1 (Front surface recombination Velocity)

It is clear from the figure that the electrical resistivity depends on thickness in the investigated range. It is also clear that the relation gives two straight lines which mean that there are two conduction mechanisms:

$$
\rho=\rho_{0} e^{\Delta E / k_{B} T}
$$

Where:

$\Delta \mathrm{E}=$ The activation energy

$\rho_{\mathrm{o}}=$ The pre-exponential factor of the resistivity.

It is found that the activation energy decreases from 0.453 to $0.392 \mathrm{eV}$ with the increase in the film thickness from 100 to $600 \mathrm{~mm}$, respectively, which may attribute to the quantum size effect.

Simulated J-V Characteristics as a Function of the Surface Recombination Velocity (Front and Back)

The variation in J-V characteristics with respect to $S 1$ is shown in Fig. 8. For most semiconductors, the surface recombination velocity is of the order of $10^{7} \mathrm{~cm} / \mathrm{s}$ but, experimentally, it has become possible to reduce the value of $S 1$ to $10^{3} \mathrm{~cm} / \mathrm{s}$. As the front surface recombination velocity increases, the values of cell performance parameters such as $\mathrm{J}_{\mathrm{sc}}, \mathrm{V}_{\mathrm{oc}}$, fill factor and efficiency decreases. Table 1 shows the calculated values of the cell parameters with the variation of $S 1$. 


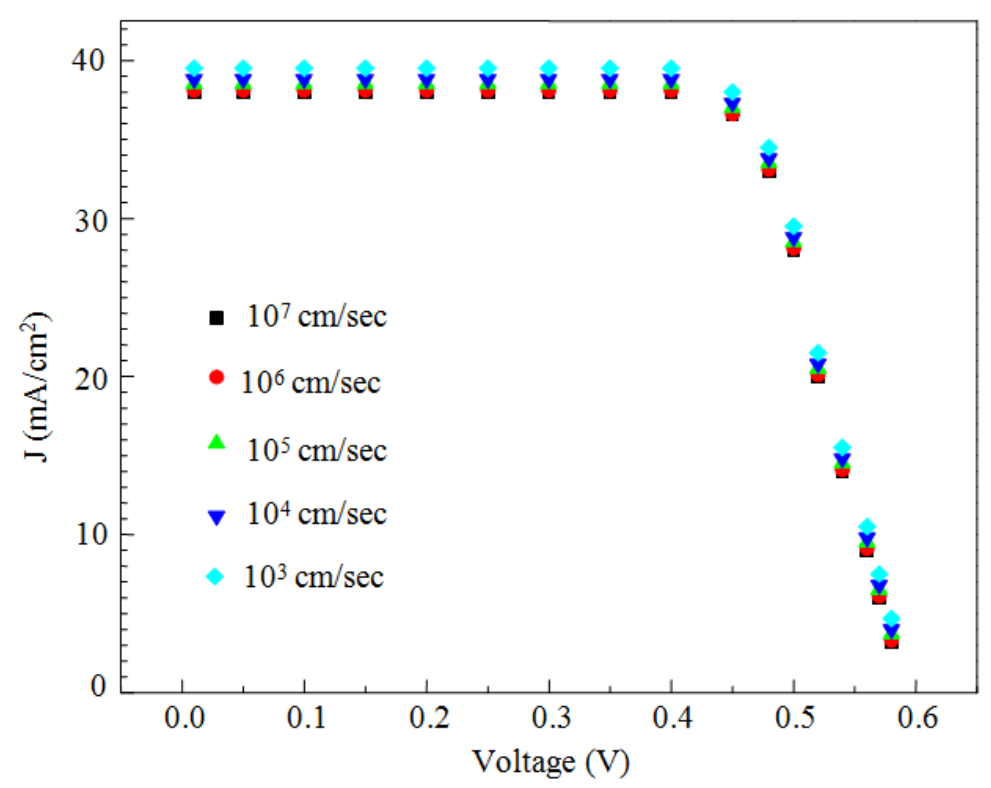

Fig. 9. Simulated J-V characteristics various values of S2 (Back Surface Recombination Velocity)

Table 1. The calculated values of the cell parameters with the variation of S1

\begin{tabular}{lllll}
\hline Front surface & & & \\
recombination velocity $(\mathrm{cm} / \mathrm{s})$ & $\mathrm{J}_{\mathrm{sc}}\left(\mathrm{mA} / \mathrm{cm}^{2}\right)$ & $\mathrm{V}_{\mathrm{oc}}(\mathrm{V})$ & Fill Factor \% & Efficiency \% \\
\hline $\mathrm{S} 1=10^{3}$ & $39 \cdot 39$ & $0 \cdot 666$ & $0 \cdot 834$ & 21.88 \\
$\mathrm{~S} 1=10^{4}$ & $39 \cdot 35$ & $0 \cdot 662$ & $0 \cdot 833$ & 21.71 \\
$\mathrm{~S} 1=10^{5}$ & $38 \cdot 18$ & $0 \cdot 640$ & $0 \cdot 824$ & 20.07 \\
$\mathrm{~S} 1=10^{6}$ & $37 \cdot 22$ & $0 \cdot 605$ & $0 \cdot 822$ & 18.53 \\
$\mathrm{~S} 1=10^{7}$ & $35 \cdot 56$ & $0 \cdot 591$ & $0 \cdot 819$ & 17.22 \\
\hline
\end{tabular}

Table 2. The calculated values of the cell parameters according to S2

\begin{tabular}{lllll}
\hline $\begin{array}{l}\text { Back surface } \\
\text { recombination velocity }(\mathrm{cm} / \mathrm{s})\end{array}$ & $\mathrm{J}_{\mathrm{sc}}\left(\mathrm{mA} / \mathrm{cm}^{2}\right)$ & $\mathrm{V}_{\mathrm{oc}}(\mathrm{V})$ & Fill Factor \% & Efficiency \% \\
\hline $\mathrm{S} 2=10^{3}$ & 39.39 & 0.666 & 0.834 & 21.88 \\
$\mathrm{~S} 2=10^{4}$ & 39.35 & 0.665 & 0.833 & 21.83 \\
$\mathrm{~S} 2=10^{5}$ & 39.2 & 0.662 & 0.833 & 21.83 \\
$\mathrm{~S} 2=10^{6}$ & 39.2 & 0.662 & 0.833 & 21.62 \\
$\mathrm{~S} 2=10^{7}$ & 39.1 & 0.659 & 0.831 & 21.47 \\
\hline
\end{tabular}

The current density also reduces as $\mathrm{S} 2$ increases (Fig. 9). It is revealed that, as S2 decreases the values of Jsc increases. This is because, as S2 increases, the carriers start recombining at the front surface which reduces the current and other associated cell parameters. For this structure, the oxidation and metallization followed by photolithography on the front surface. The metal contact helps to collect carriers and $\mathrm{SiO}_{2}$ reduces the recombination on the front surface. Table 2 shows the calculated values of the cell parameters according to $S 2$.

\section{Conclusion}

In this study, a computer simulation modeling for the $\mathrm{Au} / \mathrm{n}-\mathrm{Ti}_{2} \mathrm{~S} / \mathrm{p}-\mathrm{Si} / \mathrm{Al}$ Schottky-type thin film HIT solar cell with AFORS-HET program has been done.
It was found that with the increase of the (n) layer thickness, the short-spectrum response and the shortcircuit current density of solar cell will decrease. An intrinsic amorphous silicon layer is used to reduce the interface defect state density. If the interface state density is low, the better intrinsic thickness is no more than $5 \mathrm{~nm}$. The thickness of BSF has little effect on the conversion efficiency, while reasonable doping and band gap design can improve efficiency more than 2 percentage points. The photovoltaic parameters of HIT solar cells were $\mathrm{Voc}=678.9 \mathrm{mV}, \mathrm{J}_{\mathrm{sc}}=37.35 \mathrm{~mA} / \mathrm{cm}^{2}$, $\mathrm{FF}=83.97$ and $\eta=21.88 \%$ for back surface recombination velocity of $10^{3} \mathrm{~cm} / \mathrm{s}$. While, the photovoltaic parameters of HIT solar cells are $\mathrm{V}_{\mathrm{oc}}=666$ $\mathrm{mV}, \mathrm{Jsc}=39.39 \mathrm{~mA} / \mathrm{cm}^{2}, \mathrm{FF}=0.834$ and $\eta=21.88 \%$ of the front surface recombination velocity of $10^{3} \mathrm{~cm} / \mathrm{s}$. 


\section{Acknowledgement}

The author wishes to thank Prof. O. Shalabiea from the Physics department/faculty of Science/NBU/KSA for his revision of the article.

\section{Author's Contributions}

The author developed a computer simulation for $\mathrm{Au} / \mathrm{n}-\mathrm{Ti}_{2} \mathrm{~S} / \mathrm{p}-\mathrm{Si} / \mathrm{Al}$ Schottky-type Thin Film Heterojunction Solar Cells to perform the solar cell efficiency.

\section{Ethics}

This article is original and contains unpublished material. The corresponding author confirms that no ethical issues involved.

\section{References}

Bivour, M., C. Meinhardt, D. Pysch, C. Reichel and K. Ritzau et al., 2010. N-type silicon solar cells with amorphous/crystalline silicon hetero-junction rear emitter. Proceedings of the 35th IEEE Photovoltaic Specia-Lists Conference, Jun. 20-25, IEEE Xplore Press, Honolulu, HI, pp: 1304-1308. DOI: $10.1109 /$ PVSC.2010.5614252

Bivour, M., M. Rudiger, C. Reichel, K.U. Ritzau and M. Hermle et al., 2011. Analysis of the diffused front surface field of n-type silicon solar cells with a-Si/c-Si heterojunction rear emitter. Energy Procedia, 8: 185-192.

DOI: $10.1016 /$ j.egypro.2011.06.122

Brown, G.F., J.W. Ager, W. Walukiewicz and J. Wu, 2010. Finite element simulations of compositionally graded InGaN solar cells. Solar Energy Mater. Solar Cells, 94: 478-483.

DOI: 10.1016/j. solmat.2009.11.010.

Chakraborty, S., R. Cariou, M. Labrune, P. Rocai Cabarrocas and P. Chatterjee, 2013. The feasibility of using thin crystalline silicon films epitaxially grown at $165^{\circ} \mathrm{C}$ in solar cells: A computer simulation study. EPJ Photovoltaics, 4: 45103-45114.

DOI: $10.1051 /$ epjpv/2013014

Chen, A. and K. Zhu, 2012. Computer simulation of a$\mathrm{Si} / \mathrm{c}-\mathrm{Si}$ heterojunction solar cell with high conversion efficiency. Solar Energy, 86: 393-397. DOI: 10.1016/j.solener.2011.10.015

El-Nahass, M.M., H.M. Zeyada, M.S. Aziz and N.A. El-Ghamaz, 2005. Carrier transport mechanisms and photovoltaic properties of $\mathrm{Au} / \mathrm{p}-\mathrm{ZnPc} / \mathrm{pSi}$ solar cell. Solid State Electronic, 49: 1314-1319. DOI: $10.1016 /$ j.sse.2005.06.001
Forrest, S.R., M.L. Kaplan and P.H. Schmidt, 1984. Organic-on-inorganic semiconductor contact barrier diodes. II. Dependence on organic film and metal contact properties. J. Appl. Phys., 56: 543-551. DOI: $10.1063 / 1.333944$

Froitzheim, A., R. Stangl, L. Elstner, M.l. Kriege and W. Fuhs, 2003. Presented at the 3rd World Conference on Photovoltaic Energy Conversion, May 11-18, Osaka, Japan, pp: 272-279.

Gray, J.L., R.J. Schwartz and Y.J Lee, 1992. Development of a computer model for polycrystalline thin-film CuInSe2 and CdTe solar cells. ECE Technical Reports.

Hamakawa, Y., H. Okamoto and Y. Nitta, 1979. A new type of amorphous silicon photovoltaic cell generating more than $2.0 \mathrm{~V}$. Applied Phys. Lett., 35: 187-189. DOI: $10.1063 / 1.91031$

Haque, E., M.Q. Choudhury and T.N. Quddus, 2013. Simulation of a $\mathrm{GaP} / \mathrm{Si}$ heterojunction thin film solar cell on glass substrate. Int. J. Comput. Applic., 67: 35-38. DOI: 10.5120/11747-7394

Leendertz, C., N. Mingirulli, T.F. Schulze, J.P. Kleider and B. Rech et al., 2011. Discerning passivation mechanisms at a-Si:H/c-Si interfaces by means of photoconductance measurements. Applied Phys. Lett., 98: 202108-202111. DOI: 10.1063/1.3590254

Martın de Nicolas, S., D. Munoz, A.S. Ozanne, N. Nguyen and P.J. Ribeyro, 2011. Optimization of doped amorphous silicon layers applied to heterojunction solar cells. Energy Procedia, 8: 226-231. DOI: 10.1016/j.egypro.2011.06.128

Michael, S. and P. Michalopoulos, 2002. Application of the SILVACO/ATLAS software package in modeling and optimization of state-of-the-art photovoltaic devices. Proceedings of the 45th Midwest Symposium on Circuits and Systems Conference, Aug. 4-7, IEEE Xplore Press, pp: II651-II-654. DOI: 10.1109/MWSCAS.2002.1186946

Muller, J., B. Rech, J. Springer and M. Vanecek, 2004. TCO and light trapping in silicon thin film solar cells. Solar Energy, 77: 917-930.

DOI: $10.1016 /$ j.solener.2004.03.015

Oueriagli, A., H. Kassi, S. Hotchandani and R.M. Leblanc, 1992. Analysis of dark current-voltage characteristics of $\mathrm{Al} /$ chlorophyll $\mathrm{a} / \mathrm{Ag}$ sandwich cells. J. Appl. Phys., 71: 5523-5526.

DOI: $10.1063 / 1.350526$

Ren, B.Y., M.H. Wang, X.P. Liu and Y.L. Li, 2008. Acta Energy Solaris Sinica, 29: 126-129.

Reuter, M., W. Brendle, O. Tobail and J.H. Werner, 2009. $50 \mu \mathrm{m}$ thin solar cells with $17.0 \%$ efficiency. Solar Energy Mater. Solar Cells, 93: 704-706. DOI: 10.1016/j.solmat.2008.09.03

Rhoderick, E.H., 1978. Metal-Semiconductor Contacts. 1st Edn., Clarendon Press, Oxford, ISBN-10: 0198593236, pp: 201. 
Saron, K.M.A., M.R. Hashim, N. Allam and K. Nageh, 2013. Interface properties determined the performance of thermally grown $\mathrm{GaN} / \mathrm{Si}$ heterojunction solar cells. Solar Energy, 98: 485-491. DOI: 10.1016/j.solener.2013.09.028

Schulze, T.F., C. Leendertz, N. Mingirulli, L. Korte and B. Rech, 2011. Impact of Fermi-level dependent defect equilibration on Voc of amorphous/crystalline silicon heterojunction solar cells, Energy Procedia, 8: 282-287.

DOI: $10.1016 /$ j.egypro.2011.06.137

Smole, F., M. Topic and J. Furlan, 1994. Amorphous silicon solar cell computer model incorporating the effects of TCO/a-Si:C:H junction. Solar Energy Mater. Solar Cells, 34: 385-392. DOI: 10.1016/0927-0248(94)90064-7

Stangl, R., D. Schaffarzik, A. Laades, K. Kliefoth and M. Schmidt et al., 2004. Characterization of interfaces in amorphous/crystalline silicon heterojunction solar cells by surface photovoltage spectroscopy. Proceedings of the 19th European Photovoltaic Solar Energy Conference, Jun. 7-11, Paris, France, pp: 686-689.
Sze, M.S., 1981. Physics of Semiconductor Devices. 2nd Edn., Wiley, New York, pp: 107.

Van, C.N. and K. Potje-Kamloth, 2001. Electrical and $\mathrm{NO}_{\mathrm{x}}$ gas sensing properties of metallophthalocyanine-doped polypyrrole/silicon heterojunctions. Thin Solid Films, 392: 113-121. DOI: $10.1016 / \mathrm{S} 0040-6090(01) 00837-9$

Wunsch, F., G. Citarella, O. Abdallah and M. Kunst, 2006. An inverted a-Si:H/c-Si hetero-junction for solar energy conversion. J. Non-Crystalline Solids, 352: 1962-1966.

DOI: 10.1016/j.jnoncrysol.2006.01.034

Zeng, L., P. Bermel, Y. Yi, B.A. Alamariu and K.A. Broderick et al., 2008. Demonstration of enhanced absorption in thin film Si solar cells with textured photonic crystal back reflector. Applied Phys. Lett., 93: 221105-221105. DOI: 10.1063/1.3039787

Zhoa, J.H., A.H. Wang and M.A. Green, 1998. 19.8\% efficient "honeycomb" textured multicrystalline and 24.4\% monocrystalline silicon solar cells. Applied Phys. Lett., 73: 1991-1993. DOI: 10.1063/1.122345 